RAD Conference Proceedings, vol. 4, pp. 132-137, 2020

ISSN 2466-4626 (online) | DOI: 10.21175/RadProc.2020.28

www.rad-proceedings.org

\title{
MAIN PHYSIOLOGICAL PARAMETERS OF THE HEART RHYTHM OF COWS AND THE MATHEMATICAL ANALYSIS OF ITS VARIABILITY*
}

\author{
A.A. Oleshkevich ${ }^{* * *}$ T.V. Ippolitova1, S.V. Pozdnyakov², A.M. Nosovskiy² \\ ${ }^{1}$ Federal State Budgetary Educational Institution of Higher Education «Moscow State Academy of Veterinary \\ Medicine and Biotechnology - MVA named after K. I. Skryabin» (Moscow SAVMB), Moscow, Russia \\ ${ }^{2}$ Institute of Medical-Biological Problems, Russian Academy of Science, Moscow, Russia
}

\begin{abstract}
Authors developed a classifier that allows to identify the features of rhythm regulation according to the cows' heart activity. That has become possible as a result of studying of the heart rhythm of healthy cows of different age and functional status (pregnancy, lactation) and the mathematical analysis of the results obtained. Quantitative parameters are given to estimate the tone of the autonomic nervous system, as well as the function of automatism and the stability of the regulations. The method of mathematical analysis allows to control the work of the heart, the regulation of blood circulation and other parameters. The quantitative parameters of the mathematical analysis of heart rhythm in connection with the degree of adaptation of the animal were revealed. That can serve as a scientific basis for further determination of the functional and biological characteristics of productive animals at different stages of the physiological cycle.
\end{abstract}

Keywords: Cattle, heart rhythm, mathematical analysis

\section{INTRODUCTION}

The problem of instrumental objective assessment of the physiological state of cattle at all stages of its life cycle remains relevant $[2,3]$. This is especially necessary for the prediction of animal resistance to various diseases and the degree of adaptability to the living conditions [4]. Mentioned above could significantly improve the forecast of milk production. Nowadays, the method of heart rate variability (HRV) studying seems to be one of the promising areas of modern veterinary medicine. The HRV-analysis proved to be modern, generally accepted indicator of the functional status of various parts of the regulatory mechanism. Method is used to study and to identify the types of vegetative regulation. This allows to plan the level of physical activity of the animal. The facts of the connection of the formation of HRV with the inclusion of suprasegmental structures were obtained. This opens new opportunities for analyzing the nature of $\operatorname{HRV}[5,6]$.

Indicators of the temporal analysis of HRV [6] are: $\mathrm{M}$ - average duration of intervals $R-R$ (calculated as the quotient of dividing the sum of the intervals measured in the recording segment divided by the number of intervals in the segment) and the reciprocal of this value - average heart rate $(H R) ; M x D M n-$ variational scale - the difference between the maximum and minimum cardio-intervals, (where $M x$ is a maximum duration of cardio-interval, and $M n-$ a minimum duration of cardio-interval in the recording segment). From literature it is known that in humans with a sharp increase of the mentioned value, it is necessary to pay attention to the value of the stress index (SI), or regulatory system's voltage index (the degree of predominance of the activity of central regulation mechanisms over autonomous) [7].

Standard deviation (SDNN), or " $\sigma$ " - standard deviation of the complete array of cardio-intervals reflects the total effect of the vegetative regulation of blood circulation. Its growth or decrease indicates the predominance of parasympathetic or sympathetic influences on the heart rhythm. A sharp decrease in $\sigma$ is caused by a significant voltage of regulatory systems, when higher levels of management are involved in the regulation process. This leads to the suppression of the activity of the autonomous circuit [8].

\section{MATERIALS AND METHODS}

Considering all mentioned above, we built the following study design.

Since such a study is being conducted for the first time, it was decided to perform a study on the indices of heart rate variation in cows, totally, without dividing into groups according to age, weight, and functional state of animals. At the same time, in our study, before starting the recording of HRV, the studied animals were at rest for $5^{-10}$ minutes. The study of HRV was carried out no earlier than 1.5-2 hours after eating,

\footnotetext{
* The material that served as the basis for this article was presented at the $8^{\text {th }}$ RAD-International Conference [1].

**kompsotita@gmail.com
} 
exercise or stress, at a temperature of $20-22^{\circ} \mathrm{C}$. At the time of the study, all interferences and noises resulting in emotional arousal were eliminated. When the HRVrecording, it was ensured that the experienced animals did not take deep breaths or exhale and did not cough. Consequently, all the conditions proposed in the guidelines for the study of human heart rate variations were met [9]. used:

In variability of the heart rate analysis there were

1. Statistical methods - to calculate indicators such as SDNN, or standard deviation (expressed in milliseconds); $C V$ - the coefficient of variation $\left(C V=S D N N / M^{*} 10 O\right.$, where $M-$ mean of $R-R$ intervals, expressed as a percentage).

2. Geometric methods (variative pulsometry). According to the results obtained by this method, the voltage index, VI, was calculated. Formula used: $V I=A M o / 2 M o^{*} \quad M x D M n$, where $A M o-$ mode amplitude, $M o$ - mode, $M x D M n$ - variation scale. Mode is the most common frequency range. Its physiological meaning is that it shows the most probable level of functioning of the circulatory system. In stationary processes, the mode coincides with the value of mathematical expectation. Their difference is defined as a conditional measure of non-stationarity. Mode defines the dominant level of functioning. Mode amplitude (Амо) is the number of cardio-intervals, corresponding to the values of the mode range, which reflects the stabilizing effect of central rhythm control. The amplitude reflects the influence of the sympathetic division of the vegetative nervous system.

\section{Autocorrelation analysis.}

4. Spectral methods of heart rate analysis with the calculation of high frequency (HF), low frequency (LF), very low frequency (VLF) components.

In addition, during spectral analysis, for each component, the absolute total power in the range, the average power in the range, the maximum harmonic value and the relative value in percent of the total power in all ranges were calculated (Total Power, TP). In this case, TP is defined as the sum of powers in the HF, LF and VLF-ranges. According to the spectral analysis of heart rhythm, the following indicators were calculated: centralization index - IC $(I C=(H F+L F) / V L F) \quad$ and vago-sympathetic interaction index $L F / H F$.

\section{RESULTS AND DISCUSSION}

\subsection{Results of the study of heart rate variability}

To the study of the cardiac vascular system state in cattle is devoted as works of the middle of the last century $[3,4,10.11]$, and some modern works [2]. The authors pointed to a clearly traceable dependence of milk production on the state of the cardiovascular system of the animal. As a result of the contour analysis of the ECG-signal form, direct correlations between the individual parameters of the electrocardiogram of cows and the number of dairy products during the period of standard lactation were established. However, in the early works devoted to this problem, methods of variational analysis of heart rhythm were absent, and clinically significant signs of $E C G$ change used in analysis require special knowledge. In this regard, the methods mentioned above cannot be widely used in actual practice of animal husbandry.

Nowadays, thanks to the development of computing technology and the microprocessor industry, devices have appeared that allow us to conduct automatic, realtime studies of the dynamics of heart rhythm. This makes it possible to use these methods in the practical work of livestock breeders engaged in dairy production. Unfortunately, we were unable to find any information on the application of the method for studying heart rate variations and the development of practically relevant criteria for these indicators. In the literature on cattle veterinary and physiology, there is no classification of mathematical parametric indicators of heart rhythm, since there is also no analysis by the methods of mathematical non-linear dynamics of the cardiovascular system of productive animals $[2,3,10$, 11 .

Initially, in space medicine, and then in practical health care conditions, methods for heart-ratevariability monitoring and criteria for the physiological norm, which indicate the preservation of a sufficient level of body functional capabilities, were developed in detail $[6,7,12-14]$. At the same time, it was postulated that the homeostasis of the main systems of the body is provided with a minimum voltage of regulatory mechanisms. Accordingly, the values of most indicators of HRV should not exceed certain thresholds established for a specific species and age-sex group. This condition is realized as much as possible with a comprehensive assessment of the results of the analysis of HRV. A characteristic feature of the method is its high sensitivity to the most diverse internal and external influences. The method is based on the recognition and measurement of the time intervals between the R-R intervals of the electrocardiogram, the construction of dynamic series of cardio-intervals (cardio-intervalogram) and the subsequent analysis of the numerical series obtained by various mathematical methods. Here, the simplicity of information gathering is combined with the possibility of extracting from the data obtained the extensive and diverse information about the neurohumoral regulation of physiological functions and adaptive responses of the whole organism. [15].

Let us turn to the physiological features of the life cycle of dairy cows. The first period we pay attention to is calving. Immediately after calving (in exceptional cases, a few days before it), a cow begins to lactate, it's the so-called novo-calving phase. It lasts up to two weeks after calving and plays an extremely important role in the formation of many, including the immune, systems of a born calf. Then the period of lactation begins. It is divided into several phases. The first phase is the phase of "milking-start", when the amount of milk secreted increases progressively from day to day, from week to week. This lasts from 3 to 17 weeks after calving. The increase in milk production requires a constant increase in the "supply" of ingredients to the 
gland elements of the cow's udder in order to produce the adequate amount of milk. This imposes additional requirements on the functioning of the animal's cardiovascular system. The next phase of lactation may be slightly shorter and last for about 80 days. This lactation period without pregnancy continues until the cow is inseminated. Currently, artificial insemination of cows is practiced in exactly $80-90$ days after calving. The application of this method is combined with the specific hormonal therapy of the animal, carried out to synchronize the estrus-period in several animals at the same time. This approach allows to use the genetic material from the breeding bulls at once in a few individuals. The question of what effect this hormonal therapy can make on the activity of the cardiovascular system of a cow (in particular, on variations in heart rhythm) has not yet been studied. In turn, the very impregnation entails a significant restructuring of the animal's endocrine system. In the initial phase of period named, maximum lactation is usually observed.

After that, a gradual decrease in the lactation volume begins (recession phase, phase of lactation with pregnancy), but an increase in the size of the developing fetus occurs. During this period, the animal's cardiovascular system suffers additional loads, up to the onset of calving. Thus, the study of heart rate variability as a sufficiently sensitive indicator of the intensity of the adaptation systems of the whole organism may depend on the choice of the period (lactation phase) in which the examination will be conducted. Each period of the life cycle of the animal must have its own characteristic standards for indicators of heart rate variability. At the same time, for different periods, correlations of various strengths can be detected with various VHR-indicators. We consider it most appropriate to conduct factor analysis for each lactation period in order to determine the specific contribution of each of the studied HRVindicators to the productive function of animals.

Based on the results of the experiments, we believe that the heart rate classifier according to R. Baevsky [15-19] is generally also acceptable for analyzing of heart-rhythm characteristics in cattle. As a result of studying the characteristics of the heart rhythm of cows of different ages and functional status (pregnancy, lactation) and mathematical analysis of the results, we developed the classifier that allows to identify the features of rhythm regulation of the heart activity of cows. The quantitative parameters to assess the tone of the autonomic nervous system (ANS), automatism and regulation stability were given, also. In addition, the relationships of quantitative parameters of the mathematical analysis of a heart rhythm with the degree of adaptation of the animal were identified.

For additional control of the objectivity of the developed methodology, the degree of adaptation of the cardiovascular system of cows, determined according to the results of the analysis of the cardiac rhythm, was compared with the change in the functional activity of the sympathoadrenal system.

Analysis of cardio-intervals during long-term recording was carried out by analogy with the method of R. Baevsky. The main generally accepted parameters were considered. The cumulative effect of regulation was assessed by the heart rate (HR) and the duration of the $\mathrm{R}-\mathrm{R}$ intervals. As a result of cattle cardiac activity study, the following gradations of heart rhythm were identified (Table 1).

Table 1. Compliance of the frequency response of the cattle heart rate to the heart rate and the R-R duration of the ECG interval

\begin{tabular}{|c|c|c|}
\hline $\begin{array}{c}\text { Frequency response of } \\
\text { the heart rate }\end{array}$ & $\begin{array}{c}\mathrm{HR}, \\
\text { beats / min }\end{array}$ & $\begin{array}{c}\mathrm{R}-\mathrm{R} \\
\text { duration, sec }\end{array}$ \\
\hline Severe tachycardia & $\geq 90$ & $\leq 0.66$ \\
\hline Moderate tachycardia & $\geq 80$ & $\leq 0.75$ \\
\hline Normocardia & $>60<80$ & $>0.75<1.2$ \\
\hline Moderate bradycardia & $\leq 60$ & $\geq 1.2$ \\
\hline Severe bradycardia & $\leq 50$ & $\geq 1.4$ \\
\hline
\end{tabular}

The automatism functions were estimated by the variance value, the variation range, and the coefficient of variation. Dispersion $D$ is equal to its selective (empirical) value and is calculated by the formula:

$$
D=\frac{1}{n} \sum_{i=1}^{n}\left(X_{i}-\bar{X}\right)^{2}
$$

The value of the magnitude of a variation (the variational span of $M x D M n$ ) is the difference between the smallest and largest values of the dynamic range of $\mathrm{R}-\mathrm{R}$ intervals:

$$
M_{x} D M_{n}=X_{\max }-X_{\min }
$$

The coefficient of variation ( $\mathrm{CV}$, in percent) is replaced by its empirical characteristic and is calculated as the ratio of the standard deviation to the corresponding expected value:

$$
C V=\frac{\delta}{\bar{M}} * 100 \%
$$

The threshold for the appearance of arrhythmias was considered a $10 \%$ change in the duration of cardio-intervals from cycle to cycle at rest. In the process of adaptation to the action of factors that alter the physiological state of animals, it was possible to increase these values due to the manifestation of the cardiac component of the orienting reactions.

The sine stable rhythm in cows is characterized by the following statistical characteristics: the variation range $M x D M n \leq 0.1 \mathrm{msec}$, with a standard deviation $\delta \leq 8.16$ and a coefficient of variation $C V \leq 8.0 \%$. The excess of these values characterizes the violation of heart automatism in the form of arrhythmias of varying degrees.

The state of the autonomic nervous system, or the predominance of the tone of its departments, is characterized by the variational span of $M x D M n$, the amplitude of the mode (AMo is the ordinate value of the histogram taken in percentage corresponding to the 
A.A. Oleshkevich et al., Physiological parameters of the heart rhythm..., RAD Conf. Proc., vol. 4, 2020, 132-137

mode (Mo) and the voltage index ( $V I-$ voltage index of regulatory systems $V I=A M o / 2 M o * M x D M n)$.

A decrease in mode, i.e., the mean value of the modal class in seconds $(\mathrm{Mo} / \mathrm{sec})$ and the oscillation range (variational scope), an increase in $\mathrm{HR}$, the amplitude of the mode and the voltage index occurs when the sympathetic nervous system tone prevails. In turn, an increase in the range of oscillations, $\Delta \mathrm{M}$ $(M x D M n), \&$ a decrease in $A M o$ and $V I$ indicate a predominance of the parasympathetic nervous system tone. It is possible to distinguish 2 grades when autonomic homeostasis changes: moderate and pronounced predominance of sympathetic tone (SNS) or parasympathetic nervous system (PSNS).

The state of autonomic balance (according to R. Baevsky [15-18], "Autonomic homeostasis is preserved") and the change in tone of the SNS and PSNS characterize the parameters of Table 2.

Table 2. Possible options for tone changing of the autonomic nervous system

\begin{tabular}{|c|c|c|c|c|c|}
\hline $\begin{array}{c}\text { Autonomic balance } \\
\text { index }(A B I) \\
(A B I=A M o / \sigma R R) \\
\text { conventional units }\end{array}$ & $\begin{array}{c}\text { Autonomic rhythm } \\
\text { indicator }(A R I) \\
\left(A R I=1 / M o^{*} \sigma R R\right) \text {; } \\
\text { conventional units }\end{array}$ & $\begin{array}{l}\text { Characteristics of } \\
\text { homeostasis }\end{array}$ & $\begin{array}{l}\text { The } \\
\text { duration of } \\
\text { the cardio- } \\
\text { interval, sec }\end{array}$ & $\begin{array}{l}\text { Amplitude } \\
\text { of the mode } \\
(A M o), \%\end{array}$ & $\begin{array}{c}\text { Regulatory } \\
\text { systems voltage } \\
\text { index }(V I), \\
\text { conventional } \\
\text { units }\end{array}$ \\
\hline$>271$ & $>8.5^{*}$ & $\begin{array}{c}\text { Severe prevalence of } \\
\text { SNS }\end{array}$ & $<0.15$ & $>57$ & $>180$ \\
\hline $235^{-270^{*}}$ & $7.0-8.5^{*}$ & $\begin{array}{c}\text { Moderate prevalence of } \\
\text { SNS }\end{array}$ & $0.15^{-20}$ * & $45^{-}-56^{*}$ & $124-180^{*}$ \\
\hline $162-234^{*}$ & $5.6-7.0^{*}$ & Autonomic balance & $0.20-0.24^{*}$ & $35-44$ & $96-123^{*}$ \\
\hline $161-126^{*}$ & $5 \cdot 5^{-4.1}$ * & $\begin{array}{c}\text { Moderate prevalence of } \\
\text { PSNS }\end{array}$ & $0.25-0.29 *$ & $22-34^{*}$ & $58-95^{*}$ \\
\hline$\leq 126$ & $\leq 4.0$ & $\begin{array}{c}\text { Severe prevalence of } \\
\text { PSNS }\end{array}$ & $>0.30$ & $<22$ & $\leq 58$ \\
\hline
\end{tabular}

${ }^{*} p<0.05$

Regulation stability is characterized by dispersion of series, $D$; variation coefficient, $C V$; regulation process adequacy ratio, IARP, $(I A R P=A M o / M o)$; mode-indicator, $M o$ and autonomic rhythm indicator $(A R I)\left(A R I=1 / M o^{*} \sigma R R\right)$ (Table 3$)$.

Table 3. The indicators characterizing the prevailing type of heart rhythm regulation

\begin{tabular}{|c|c|c|c|c|}
\hline 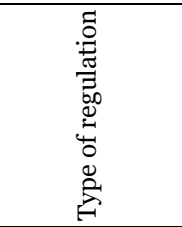 & 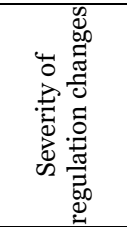 & 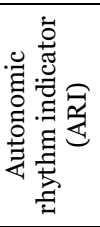 & $\stackrel{0}{\sum^{0}}$ & 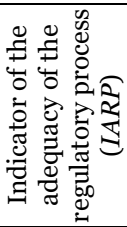 \\
\hline \multirow{2}{*}{$\begin{array}{l}\text { Dysregulation } \\
\text { with } \\
\text { predominance } \\
\text { of SNS }\end{array}$} & severe & $\leq 3.0$ & $<0.66$ & $>72$ \\
\hline & moderate & $\leq 3.0$ & $\begin{array}{c}0.74- \\
0.66\end{array}$ & $57-71$ \\
\hline \multicolumn{2}{|c|}{ Sustainable regulation } & $3-9$ & $\begin{array}{c}0.75^{-} \\
0.98\end{array}$ & $43-56$ \\
\hline \multirow{2}{*}{$\begin{array}{l}\text { Dysregulation } \\
\text { with } \\
\text { predominance } \\
\text { of PSNS }\end{array}$} & moderate & $\geq 1.0$ & $>1.17$ & $<28$ \\
\hline & severe & $\geq 10$ & $\begin{array}{c}1.08- \\
1.17\end{array}$ & $29-42$ \\
\hline
\end{tabular}

Adaptation disorder is accompanied by a change in regulation with predominance of SNS or PSNS. In this regard, the calculation and analysis of the functional activity of the relevant parts of the nervous system were carried out.

\subsection{Results of the study of heart rate variability}

The main indices that allow to assess the degree of activity of individual sections of the ANS and central nervous system in the regulation of the heart activity of cows were found. The range of variations in the duration of cardio-intervals ranged from 0.12 to $0.40 \mathrm{sec}$ and averaged $0.220 \pm 0.007 \mathrm{sec}, \Delta \mathrm{M} \pm \delta \Delta \mathrm{M}$ was in the range of $0.22 \pm 0.06(\mathrm{CV}-30 \%)$. The amplitude of the heart rate mode varies from 12 to $79 \%$ and, on the average, is $40 \pm 2(\mathrm{CV}-40 \%)$.

Autonomic balance index $(A B I)$, which determines the ratio of the contribution of the sympathetic and parasympathetic systems to the regulation of cardiac activity, varies from 30 to 550 units. In animals with severe cardiac syndromes, $A B I$ was equal:

- for bradycardia $-155.3 \pm 8.3$.

- tachycardia $-211.4 \pm 29.1$.

- for normocardia - 187-197.

The voltage index reflects the degree of centralization of heart rhythm control (the norm for human is from 50 to 200). VI in the experimental groups of animals varies from 10 to 350 units. On average, the index was $123 \pm 8$. VI increases in direct proportion to heart rate $(H R)$ in the frequency range from 50 to 90 beats per minute, amounting to $75.7 \pm 3.1$ with $H R 50-60$ beats/min, reaching $157 \pm 23$ with HR 81-90 $(\mathrm{P}>0.99)$. Then when $H R>90$ beats/min VI decreases, indicating a transition of the system to another level of functioning.

The vibration range of the cardio-intervals $(M x D M n)$ decreases in the frequency range of 71-80 and remains at the same level at other frequencies. In bradycardia, the swing is higher. In the frequency range from 40 to $70-80$ beats per minute the $A R I$ (autonomic rhythm indicator) increases from $3.3 \pm 0.7$ to $13.9 \pm 4.4(p>0.95)$ and remains high in animals with tachycardia phenomena.

IARP (Indicator of the adequacy of the regulatory process) is not closely related to the frequency characteristics of the cardiac activity and it remains to 
A.A. Oleshkevich et al., Physiological parameters of the heart rhythm..., RAD Conf. Proc., vol. 4, 2020, 132-137

be the most stable indicator. When the regulation is adequate, IARP reaches $49.8 \pm 2.5$ (38-46 units.). At the same time, in cows with severe bradycardia IARP are slightly lower, and in cows with tachycardia syndrome this index is higher than the average values.

Table 4. Normal values of indicators of mathematical analysis of the duration of cardio-intervals with satisfactory adaptation to the conditions of maintenance and exploitation of animals

\begin{tabular}{|c|c|c|c|c|}
\hline Indicator & $\mathrm{M} \pm \mathrm{M}$ & $\delta$ & $\begin{array}{c}\text { Range of } \\
\text { values, } \\
\text { min-max }\end{array}$ & $\begin{array}{c}\mathrm{CV}, \\
\%\end{array}$ \\
\hline $\mathrm{M}, \mathrm{sec}$ & $0.220 \pm 0.007$ & 0.065 & $0.20-0.24$ & 29.5 \\
\hline $\mathrm{Amo}$ & $39.5 \pm 1.8$ & 15.7 & $35-44$ & 39.7 \\
\hline$V I$ & $119 \pm 9$ & 61.0 & $96-123$ & 51.4 \\
\hline $\mathrm{ABI}$ & $198 \pm 12$ & 108 & $167-229$ & 54.5 \\
\hline $\mathrm{ARI}$ & $6.30 \pm 0.25$ & 2.2 & $5.6-7.0$ & 35.0 \\
\hline
\end{tabular}

Table 4 shows the normal values of the indicators of the mathematical analysis of the duration of cardiointervals with a satisfactory adaptation to the conditions of maintenance and exploitation of animals. $\delta$ is one of the main indicators of heart rate variability. It characterizes the state of the regulation mechanisms and indicates the cumulative effect of influences on the sinus node of the ANS. Its increase or decrease indicates a shift in autonomic homeostasis. Exceeding the specified limits by $\pm 1 \delta$ indicates the development of voltage, the deviation of $\pm 2 \delta$ indicates unsatisfactory adaptation.

A change of these parameters by $\pm 3 \delta$ indicates a breakdown of homeostasis. This interpretation of the results obtained obeys the mathematical pattern of the normal distribution.

\section{CONCLUSION}

The functioning of a living system is subject to general biological oscillatory processes that have certain amplitude and limits of motion. At the same time, the analysis of HRV can be considered a reliable method for estimating of the time-varying integral characteristics of all functional systems [13, 16-19]. The method of mathematical analysis allows to control the work of the heart, the regulation of blood circulation and other parameters. HRV analysis has established itself as an indicator of adaptation-adaptive processes not only in relation to the cardiovascular system, but also to the whole organism. The results of this study confirmed this statement. They showed that even a survey of cattle without considering the characteristics of the physiological stage of the animal's life cycle, indicates a difference in the quantitative characteristics of the studied parameters. That allows to establish a reference series of standard indicators for these species of animals and to develop an algorithmic approach to determine the individual characteristics of each animal. The algorithm developing will help to solve the problem of scientifically based forecasting of cattle productivity.

\section{REFERENCES}

1. A.A. Oleshkevich, "Mathematical analysis of cow heart rate variability," in Book of Abstr. $8^{\text {th }}$ Int. Conf. Radiation and Applications in Various Fields of Research (RAD 2020), Virtual conference, 2020, p. 16.

Retrieved from:

https://www.rad-conference.org/Book of AbstractsRAD 2020.pdf

Retrieved on: Sept. 23, 2020

2. М. Ю. Афанасьев, “Молочная продуктивность коров в связи с особенностями их сердечно-сосудистой системы," Автореф. дисс. на соискание уч. степени кандидата сельскохозяйственный наук, РФ, 2005, 22 с. (M. Yu. Afanasyev, "Milk productivity of cows in connection with the peculiarities of their cardiovascular systems," Abstracts of Ph. D. dissertations, RF, 2005, p. 22)

Retrieved from:

https://www.dissercat.com/content/molochnayaproduktivnost-korov-v-svyazi-s-osobennostyami-ikhserdechno-sosudistoi-sistemy Retrieved on: Oct.17, 2020

3. А. П. Двойнина, Материалы no электрокардиографии высокопродуктивных коров: Физиологические основы электрокардиографии животных, Москва, СССР: Наука, 1958, с. 75-79.

(A. P. Dvoynina, Materials on electrocardiography of highly productive cows: Physiological basis of electrocardiography of animals, Moscow, USSR: Science, 1958, pp. 75-79)

4. Л.Г. Кротова, "Влияние уровня молочной продуктивности коров на их сердечную деятельность," Труды Свердловского с.х. института, Свердловск, СССР: СвСХИ, 1958, с. 211-214

(L. G. Krotova, "The impact of the level of milk production of cows on their heart activity," in Book of Proceedings of the Sverdlovsk Institute, Sverdlovsk, USSR, 1958, pp. 211-214).

5. В. М. Покровский, “Формирование ритма сердияа в организме человека и животных”, Краснодар, РФ: Кубань-Книга, 2007, 144 с.

(V. M. Pokrovsky, "Formation of the heart rhythm in humans and animals", Krasnodar, RF: Kuban-Book, 2007, 144 p.)

Retrieved from:

https://docplayer.ru/69145193-V-m-pokrovskiyformirovanie-ritma-serdca-v-organizme-cheloveka-izhivotnyh.html

Retrieved on: Oct.17, 2020

6. Н. И. Шлык, Сердечный ритм и тип регуляции у детей, подростков и спортсменов, Ижевск, РФ: Удмуртский университет, 2009, 259 с.

(N. I. Shlyk, Heart rate and type of regulation in children, adolescents and athletes, Izhevsk, RF: Udmurt University Publishing House, 2009, 259 p.)

Retrieved from:

http://fpbswimming.ru/file/Ритм_сердца_у детей_по дростков и спортсменов.pdf

Retrieved on: Oct.17, 2020

7. Л. А. Бокерия, О. Л. Бокерия, И. В. Волковская, "Вариабельность сердечного ритма: методы измерения, интерпретация, клиническое использование", Анналы аритмологии, № 4, с. 21-32, 2009. 
A.A. Oleshkevich et al., Physiological parameters of the heart rhythm..., RAD Conf. Proc., vol. 4, 2020, 132-137

(L. A. Bockeria, O. L. Bockeria, I. V. Volkovskaya, "Heart rate variability: measurement methods, interpretation, clinical use," Annals of Arrhythmology, № 4, pp. 21-32, 2009).

8. Р.М. Баевский и др., “Анализ вариабельности сердечного ритма при использовании различных электрокардиографических систем,” Вестник аритмологии, №24, с. 65-87, 2001.

(R. M. Baevsky et. al., "Analysis of heart rate variability using different electrocardiographic systems", Bulletin of Arrhythmology, № 24, pp. 65-87, 2001.)

Retrieved from:

https://www.dissercat.com/content/molochnayaproduktivnost-korov-v-svyazi-s-osobennostyami-ikhserdechno-sosudistoi-sistemy

Retrieved on: Oct.17, 2020

9. Методические рекомендации по анализу вариабельности сердечного ритма у спортсменов в видах спорта на выносливость с применением математических методов, [электр. ресурс], Москва, $\mathrm{P} \Phi, 2013,65 \mathrm{c}$.

(Guidelines on the analysis of heart rate variability in athletes in sports endurance using mathematical methods [electronic resource], Moscow, RF, 2013, 65 p.)

Retrieved from:

https://docplayer.ru/37200655-Metodicheskierekomendacii-po-analizu-variabelnosti-serdechnogoritma-u-sportsmenov-v-vidah-sporta-na-vynoslivost-sprimeneniem-matematicheskih.html

Retrieved on: Oct. 17, 2020

10. Б. С. Никольский, "Новые данные по электрокардиографическим исследованиям крупного рогатого скота", Всес. сов. по физиологии и биохимии с.х. животных. Москва, СССР, 1959, 312 с.

(B. S. Nikolsky, "New data on electrocardiographic studies of cattle", in Book of Abstr. of All-Union. Councils on the Physiology and Biochemistry of Animals, Moscow, USSR, 1959, 312 p.)

11. И. В. Филатов, "Клиническая электрокардиография у сельскохозяйственных животных", Автореф. дисс. док. вет. наук, СССР, 1959, 40 с.

(I. V. Filatov "Clinical electrocardiography in farm animals", Abstract of the Doctor Vet. Dissertation, USSR, $1956,40 \mathrm{p}$.)

12. А. И. Григорьев, Р. М. Баевский, Концепция здоровъя и космическая медицина, Москва, РФ: Слово, 2007, 208 c.

(A. I. Grigoriev, R. M. Baevsky, Concept of health and space medicine, Moscow, RF: Word, 2007, 208 p.) Retrieved from:

https://search.rsl.ru/ru/record/01003356783

Retrieved on: Oct. 17, 2020

13. Р. М. Баевский, Г. Г. Иванов, "Вариабельность сердечного ритма: теоретические аспекты и возможности клинического применения", Ультразвуковая и функциональная диагностика, № 3 , c. 108-127, 2001

(R. M. Baevsky, G. G. Ivanov "Heart rate variability: theoretical aspects and possibilities of clinical use", Ultrasound and functional diagnostics, № 3, pp. 106-127, 2001.

Retrieved from:

https://www.elibrary.ru/item.asp?id=25990135
Retrieved on: Oct.17, 2020

14. A. M. Wawryk, D. J. Bates, J. J. Couper "Power spectral analysis of heart rate variability in children and adolescents with IDDM", Diabetes Care, vol. 20, no. 9, pp. 1416-1421, 1997. https://doi.org/10.2337/diacare.20.9.1416 PMID: 9283789

15. Р. М. Баевский, О. И. Кириллов, С. З. Клецкин, Математический анализ изменений сердечного ритма при стрессах, Москва, РФ: Наука, 1984. 220 с. (R. M. Baevsky, O. I. Kirillov, S. Z. Kletskin, Mathematical analysis of changes in heart rate during stress, Moscow, RF: Science, 1984, 220 p.)

Retrieved from:

https://search.rsl.ru/ru/record/01001228908 Retrieved on: Oct.17, 2020

16. Р. М. Баевский, Г. Г. Иванов, "Вариабельность сердечного ритма: основы метода и новые направления", Новые методы электрокардиографии, Москва, РФ: Техносфера, 2007, c. 473-496.

(R. M. Baevsky, G. G. Ivanov, "Heart rate variability: fundamentals of the method and new directions", New methods of electrocardiography, Moscow, RF: Technosphere, 2007, pp. 473-496.)

Retrieved from:

http://www.technosphera.ru/lib/book/43? read=1 Retrieved on: Oct.17, 2020

17. Р. М. Баевский, А. П. Берсенева, Оценка адаптационных возможностей организма и риск развития заболеваний, Москва, РФ: Медицина, 1997, $236 \mathrm{c}$.

(R. M. Baevsky, A. P. Berseneva, Evaluation of the adaptive capacity of the organism and the risk of developing diseases, Moscow, RF: Medicine, 1997, 265 p.)

Retrieved from:

https://studopedia.info/2-119367.html

Retrieved on: Oct.17, 2020

18. Отв. ред. Н. И. Шлык., Р. М. Баевский, Ритм сердца и тип вегетативной регуляции в оценке уровня здоровья населения и функииональной подготовленности спортсменов: материалы VI Bсерос. симп., Ижевск, РФ: Удмуртский университет, $2016,608 \mathrm{c}$.

(ex. editor N. I. Shlyk., R. M. Baevsky, "Heart rhythm and type of autonomic regulation in the assessment of the level of health of the population and the functional preparedness of athletes," Materials of VI All-Un. Simp., Izhevsk, RF: Udmurt University Publishing Center, 2016, 608 p.)

Retrieved from:

https://www.elibrary.ru/item.asp?id=27210254 Retrieved on: Oct. 17, 2020

19. С. Н. Коренева, К. Б. Петров, "Способ коррекции вегетативного баланса организма спортсменов," Патент РФ № 2373975, РФ, ноябрь, 2009.

(S. N. Koreneva, K. B. Petrov, "Method of correction of the vegetative balance of the body of athletes," RF patent no. 2373975, RF, Nov. 2009)

Retrieved from:

http://allpatents.ru/patent/2373975.html

Retrieved on: Oct. 17, 2020 